\title{
METHANE PRODUCTION FROM CASSAVA STARCH WASTEWATER IN PACKED-BED REACTOR AND CONTINUOUS FLOW
}

\author{
Izabela R. C. Araujo ${ }^{*}$, Simone D. Gomes ${ }^{2}$, Tamiris U. Tonello², Shaiane Dal'Maso Lucas ${ }^{2}$, \\ Angelo G. Mari' ${ }^{2}$, Rodrigo J. de Vargas ${ }^{3}$
}

${ }^{1 *}$ Corresponding author. Westem Paraná State University/ Cascavel - PR, Brasil. E-mail: izabelarcaraujo@gmail.com

\section{KEYWORDS}

methanogenic reactor, anaerobic biodigestion, biogas.

\begin{abstract}
The aim of this study was to evaluate the behavior of an anaerobic reactor of packed-bed and continuous flow, in relation to the biogas and methane production and the removal of organic load, from the wastewater of cassava starch extraction. For this purpose, were tested, in a reactor with a useful volume of $2.82 \mathrm{~L}$ and support mean of polypropylene filled with polyethylene foam, the organic loading rate (OLR) of 2.5, 5.0, 8.0 and $10.0 \mathrm{~g}$ $\mathrm{L}^{-1} \mathrm{~d}^{-1}$. It was evaluated the removal of COD, the $\mathrm{pH}$, the VA/TA ratio, the biogas and the methane production. It was concluded from this study that it is possible to produce biogas with methane percentages higher than $80 \%$ (maximum) and remove the organic load more than $90 \%$ under the tested conditions. In relation to stability, the reactor can be considered stable for the parameters, $\mathrm{pH}$, the relationship between volatile acidity and total a kalinity and organic load removal. The best results in relation to the average volumetric biogas production $\left(0.174\right.$ and $\left.0.311 \mathrm{~L} \mathrm{~g} \mathrm{COD}^{-1}\right)$ were obtained for the higher organic loading rate (of 8 and $10 \mathrm{~g} \mathrm{~L}^{-1} \mathrm{~d}^{-1}$, respectively) and the observed tendency is that with the increase of the organic loading rate, the specific biogas production will increase as well as the specific production of methane.
\end{abstract}

\section{INTRODUCTION}

The search for energy sustainability, especially in the industrial sector, involves the introduction of clean and renewable sources of energy. On the other hand, tailings and industrial wastewater can provide a source of substrates for the biological production of combustible gases, such as methane and hydrogen, contributing to the energy supply of these industries. Thus, the alternatives for the biological production of these gases, from tailings, have been consolidating as a vast and promising field of research.

Effluents from cassava starch extraction have excellent potential for anaerobic digestion. This is because these effluents presented high organic load, especially represented by the sugars. In addition, they are generated in large quantities, reaching $60 \mathrm{~m}^{3}$ of effluent per ton of processed cassava (Sun et al., 2012). In this context, several researches have been carried out to evaluate the biogas production from the digestion of the starch effluents, varying both, the operating conditions and the configuration of the reactors (Colin et al., 2007; Larsen et al., 2013; Sun et al., 2012; Andreani et al., 2015; Khongkliang et al., 2015; Kuczman et al., 2016; Pereira et al., 2016).

Among the configurations, the packed-bed reactors stand out for promoting the fixation of the biomass, limiting its drag out of the reactor. This reactor configuration also allows the operation without the need for recirculation or temperature conditioning, except in regions whose average temperatures are less than $25^{\circ}$ (Peixoto et al., 2011). Another advantage of the system is that it can be used the support mean occupying only a part of the useful volume of the reactor, which in relation to other configurations reduces costs (Boonapatcharoen et al., 2007; Peixoto et al., 2011).

Some studies have evaluated the efficiency of biogas production in packaged-bed reactors. Using the wastewater from cassava starch extraction, Colin et al. (2007) evaluated the methane production in a horizontal anaerobic reactor with continuous flow, partially filled with pieces of bamboo in a packed-bed. Using the same

\footnotetext{
${ }^{2}$ Western Paraná State University/ Cascavel - PR, Brazil.

${ }^{3}$ Federal University of Technology - Paraná / Medianeira - PR, Brazil.

Received in: 8-21-2017

Accepted in: 1-18-2018
} 
substrate, Kunzler et al. (2013) tested the methane production, in horizontal reactors, with different diameter:length ratios, containing bamboo support mean, and varying the values of organic loading rates. Larsen et al. (2013), using this same reactor configuration, obtained an increase in the volumetric biogas production with the addition of glycerin to the wastewater from the starch extraction; Kuczman et al. $(2014,2016)$ evaluated the biogas production and methane yield in a pilot scale reactor with packed-bed of bamboo stalks and biogas recircu lation inside the reactor.

The configuration of vertical reactor with packaged-bed and continuous flow, has already been tested by Lucas et al. (2014), Andreani et al. (2015) and Torres et al. (2017), using as substrate the starch extraction wastewater, with the objective of producing hydrogen, obtaining up to $6.34 \mathrm{~L}_{\mathrm{H} 2} \mathrm{~d}^{-1} ; 1.1 \mathrm{~L}_{\mathrm{H} 2} \mathrm{~d}^{-1} \mathrm{~L}^{-1}$ and $0.25 \mathrm{~L}_{\mathrm{H} 2} \mathrm{~d}^{-1}$, respectively. Once evaluated its viability for hydrogen production in different conditions, it sought to evaluate its performance in relation to the production of methane from the same substrate.

In general, the results of the studies converge towards the variation of the biogas production, and the percentage of the combustible gas, being it methane or hydrogen, in relation to the organic load of the substrate. Then considering the recent research history using packaged-bed and continuous flow reactors for biogas production, it was proposed with this study to evaluate the behavior of a reactor with this configuration, in relation to biogas production and, more specifically, the methane, associated to the removal of the organic load, by varying the organic loading rate.

\section{MATERIAL AND METHODS}

A vertical, upward flow anaerobic reactor made of transparent plexiglass, $5 \mathrm{~mm}$ thick, $75 \mathrm{~cm}$ high, $8 \mathrm{~cm}$ internal diameter, a total volume of $3.64 \mathrm{~L}$ and a useful volume of 2.82 was used. It was divided in three compartments, separated by wire mesh, according to the configurations presented by Andreani et al. (2015). Polypropylene rings with expanded polyurethane (foam) filling, $1.5 \mathrm{~cm}$ in diameter by $2 \mathrm{~cm}$ in length, were used as support mean. The reactor was kept in a climatized room at $25^{\circ} \mathrm{C}$

In the inoculation of the reactor, it was used sludge fro $m$ another experimental anaerobic reactor, also fed with starch wastewater, in the proportion of $30 \%$ of sludge (846 $\mathrm{mL})$ and $70 \%$ of wastewater $(1974 \mathrm{~mL})$. The solution was recirculated for a period of 5 days and then it started the reactor feeding.

The reactor was monitored daily for a period of 122 days, including inoculation, starting and conduction. After the stabilization of the system, evaluated mainly as a function of the VA/TA ratio $<0.5$, according to Silva (1977), data were collected for 20 days. Increased gradually, without reinoculation, the OLR up to 5.0, 8.0 and $10.0 \mathrm{~g} \mathrm{~L}^{-1} \mathrm{~d}^{-1}$, consecutively, samples were collected for 20 days for each OVL after the stabilization period.

The reactor was fed continuously and subjected to organic load rate (OLR) of 2.5, 5.0, 8.0 and $10.0 \mathrm{~g} \mathrm{~L}^{-1} \mathrm{~d}^{-1}$, with hydraulic holding times (HHT) of 3.45, 1.72, 1.08 and 0.77 days.

The biogas production was quantified daily by the gasometer system based on the Mariotte principle, which contained acidulated saline solution, of $3 \%$ of $\mathrm{H}_{2} \mathrm{SO}_{4}$ and $25 \% \mathrm{NaCl}$.

It was used as substrate (reactor affluent) the effluent from the production of cassava starch, collected in a cassava starch industry. The collected effluent came from the operations of extraction and concentration of the starch. The physicochemical properties of the collected wastewater are presented in Table 1 , based on the averages of the weekly analy zes.

TABLE 1. Physical-chemical characteristics of the effluent samples used to feed the reactor.

\begin{tabular}{|c|c|c|}
\hline Characteristic & 1st Batch* & 2nd Batch* \\
\hline $\mathrm{pH}$ & 4.4 & 6.4 \\
\hline $\mathrm{COD}_{\mathrm{S}}\left(\mathrm{mg} \mathrm{L}^{-1}\right)$ & 6792.3 & 7715.3 \\
\hline $\mathrm{COD}_{\mathrm{T}}\left(\mathrm{mg} \mathrm{L}^{-1}\right)$ & 8048.9 & 12581.2 \\
\hline $\operatorname{TSS}\left(\mathrm{mg} \mathrm{L}^{-1}\right)$ & 1226.3 & 2070.0 \\
\hline $\operatorname{VSS}\left(\mathrm{mg} \mathrm{L}^{-1}\right)$ & 1157.5 & 1940.0 \\
\hline $\mathrm{FSS}\left(\mathrm{mg} \mathrm{L}^{-1}\right)$ & 68.8 & 130.0 \\
\hline $\operatorname{KTN}\left(\mathrm{mg} \mathrm{L}^{-1}\right)$ & 200.2 & 294.0 \\
\hline
\end{tabular}

* average values of weekly samplings. CODs - Chemical demand for soluble oxygen; CODt - Chemical demand for total oxy gen. TSS Total suspended solids; VSS - Volatile suspended solids; FSS - Fixed suspended solids, KTN- Kjeldahl total nitrogen.

The first batch of effluent was used until the $89^{\text {th }}$ day of monitoring of the reactor and the second until the end of the operation. The reactor was monitored daily for a period of 122 days, including inoculation, starting and conduction, starting from the OLR of $2.5 \mathrm{~g} \mathrm{~L}^{-1} \mathrm{~d}^{-1}$. The stabilization of the system was evaluated mainly as function of the ratio of volatile acidity by total alkalinity (VA/TA), being considered as recommended value relation VA/TA $<0.5$, according to Silva (1977).

The $\mathrm{pH}$ of the effluent was monitored daily at the exit of the reactor through the Potentiometric method 4500-H+ (APHA, AWWA, WEF, 2017), temperature, COD (total and soluble) by the Colorimetric $-5220 \mathrm{D}$ method (APHA, AWWA, WEF, 2017), volatile acidity (VA), total alkalinity (TA) by the titrimetric method described by Silva (1977), total and volatile solids, total suspended solids and fixed and volatile suspensions by Gravimetric Method 2540 (APHA, AWWA, WEF, 2017) and biogas production. The volatile organic acids were monitored weekly and the composition of the biogas was monitored three times a week.

The concentrations of organic acids (lactic, acetic, butyric and propionic) were determined using a high performance liquid chromatograph (Shimadzu Prominence HPLC) equipped with an Aminex ${ }^{\circledR}$ HPX-87H column as described by Penteado et al. (2013). 
The biogas composition was determined by Gas Chromatography on the GC-2010 SHIMADZU $^{\circledR}$ Chromatograph, equipped with a thermal conductivity detector (TCD), with Supelco Carboxen ${ }^{\circledR} 1010$ Plot column $(30 \mathrm{~m} \quad \mathrm{x} \quad 0.53 \mathrm{~mm}$ outside diameter, $0.30 \mu \mathrm{m}$ thickness), using Argon as the dragging gas. The injector and detector temperatures were $150^{\circ} \mathrm{C}$ and $240^{\circ} \mathrm{C}$, respectively. The column temperature was $230^{\circ} \mathrm{C}$ with heating of $46^{\circ} \mathrm{C} \mathrm{min}^{-1}$ to $230^{\circ} \mathrm{C}$. One hundred microliters of the gas sample were injected in duplicate.
The response variables used to evaluate the reactor performance in different conditions were the removal of COD (\%), volatile acidity/total alkalinity ratio, specific biogas production ( $\left.\mathrm{L} \mathrm{g} \mathrm{COD}_{\text {consumed }^{-1}}\right)$, specific methane production $\left(\mathrm{L} \mathrm{g} \mathrm{COD}\right.$ consumed $\left.^{-1}\right)$, concentration of volatile acids $\left(\mathrm{mg} \mathrm{L}^{-1}\right)$.

\section{RESULTS AND DISCUSSION}

In the Table 2 are shown the average $\mathrm{pH}$ values, COD removal efficiencies, VA/TA ratio, specific biogas production and specific methane production.

TABLE 2. Average values and standard deviation of the parameters monitored during the conduction of the experiment for each condition of organic loading rate (OLR).

\begin{tabular}{cccccccccc}
\hline \multirow{2}{*}{$\begin{array}{c}\text { OLR } \\
\left(\mathrm{g} \mathrm{L}^{-1} \mathrm{~d}^{-1}\right)\end{array}$} & $\mathrm{pH}$ & \multirow{2}{*}{$\begin{array}{c}\text { Removal of } \\
\text { COD }(\%)\end{array}$} & \multirow{2}{*}{$\mathrm{VA} / \mathrm{TA}$} & \multicolumn{3}{c}{$\begin{array}{c}\text { Concentration of volatile acids } \\
\left(\mathrm{g} \mathrm{L}^{-1}\right)\end{array}$} & \multicolumn{3}{c}{$\begin{array}{c}\text { Specific production } \\
\left(\mathrm{Lg} \mathrm{COD}^{-1} \text { consumed }\right.\end{array}$} \\
\cline { 5 - 10 } & & & & Lactic & Acetic & Butyric & Propionic & Biogas & Methane \\
\hline 2.5 & $8.4 \pm 0.3$ & $98.4 \pm 0.3$ & $0.08 \pm 0.06$ & $70.5 \pm 122.1$ & $266 \pm 218$ & $175 \pm 196$ & $107.2 \pm 64.9$ & $0.03 \pm 0.01$ & $0.03 \pm 0.01$ \\
5 & $8.4 \pm 0.2$ & $98.6 \pm 0.1$ & $0.11 \pm 0.04$ & $39.6 \pm 17.1$ & $109.6 \pm 11.8$ & $44.7 \pm 8.1$ & $39.7 \pm 1.1$ & $0.09 \pm 0.06$ & $0.08 \pm 0.05$ \\
8 & $8.1 \pm 0.4$ & $99.0 \pm 0.3$ & $0.26 \pm 0.09$ & $4.13 \pm 7.1$ & $70.6 \pm 16.3$ & $35.7 \pm 25.1$ & $42.1 \pm 18$ & $0.17 \pm 0.11$ & $0.11 \pm 0.05$ \\
10 & $8.0 \pm 0.5$ & $98.9 \pm 0.3$ & $0.40 \pm 0.18$ & 0 & $109.6 \pm 91.3$ & $84.4 \pm 37.1$ & $80.7 \pm 71.9$ & $0.31 \pm 0.11$ & $0.22 \pm 0.12$ \\
\hline
\end{tabular}

COD -Chemical demand for oxygen; VA/TA - Relationship between volatile acidity and total alkalinity.

The reactor remained stable in relation to the monitored operating parameters. The $\mathrm{pH}$ averages, for the 4 conditions tested, can be considered high in relation to the optimum range of operation defined by Ward et al. (2008), which varies from 6.8 to 7.2, however, according to Campos et al. (2006), the fact that there were few variations and higher values of $\mathrm{pH}$, indicate good buffering condition in the reactor. Values of $\mathrm{pH}$ above the usual range for anaerobic reactors were also found by Kuczman (2012) when operating a pilot scale horizontal reactor in the treatment of starch effluent, recording $\mathrm{pH}$ values in the range of 5.71 to 8.61. According to the author, the COD reduction has a negative relationship with the VA/TA ratio, that is, high COD reductions occur under low acidity conditions, associated with reduction of COD organic matter with increasing alkalinity in the reactor (Zinatizadeh et al., 2010). In the present study, high COD removals were observed and alkalinity was always in evidence compared to the acidity of the system, contributing to a VA/TA ratio within the standard adopted for anaerobic reactors.
The composition of the effluent, with the presence of organic nitrogen compounds, may also have contributed to raise these $\mathrm{pH}$ values, since the alkalinity of bicarbonates according to Palma (2012) constitutes the main source of buffer capacity in the neutral $\mathrm{pH}$ range and may be generated by anaerobic conditions, by the degradation of organic nitrogen compounds, soaps or salts of organic acids, reduction of sulfites and sulfates.

The mean values of the VA/TA ratio were within the optimum range of operation, ranging from 0.1 to 0.5 , considered stable by Sanchez et al. (2005). However, in the last condition tested, with organic loading rate equal to $10.0 \mathrm{~g} \mathrm{~L}^{-1} \mathrm{day}^{-1}$, some values extrapolated the upper limit of stability mentioned above. Comparatively, even when operating with organic loading rate relatively higher than those applied by Kuczman et al. $(2014,2016)$ and by Larsen et al. (2013), the system remained more stable, considering $\mathrm{pH}$ and VA/TA ratio. Although there was no drop in $\mathrm{pH}$, it is verified, from Figure 1, that the volatile acidity shows an increase from the OLR of 8.0 and $10.0 \mathrm{~g}$ $\mathrm{L}^{-1} \mathrm{day}^{-1}$.

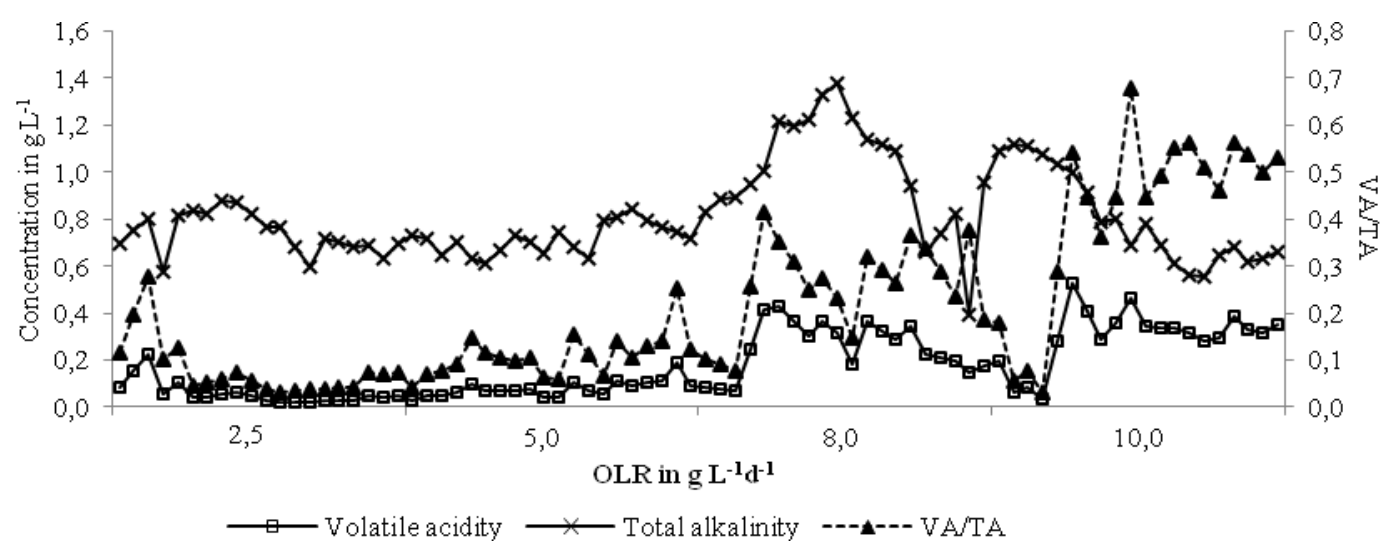

FIGURE 1 .Variation of volatile acidity concentrations, total alkalinity and VA/TA as function of organic loading rate (OLR 2.5, 5.0, 8.0 and $\left.10.0 \mathrm{~g} \mathrm{~L}^{-1} \mathrm{~d}^{-1}\right)$. 
The presence of lactic, acetic, propionic and butyric acids was identified in the evaluation of the organic acids in the reactor effluent. For all organic loading rates tested, the highest mean acid concentrations obtained were acetic acid, follo wed by butyric acid concentrations, except for $8.0 \mathrm{~g} \mathrm{~L}^{-1} \mathrm{~d}^{-1}$, where the concentration of propionic acid was higher than that of butyric acid.

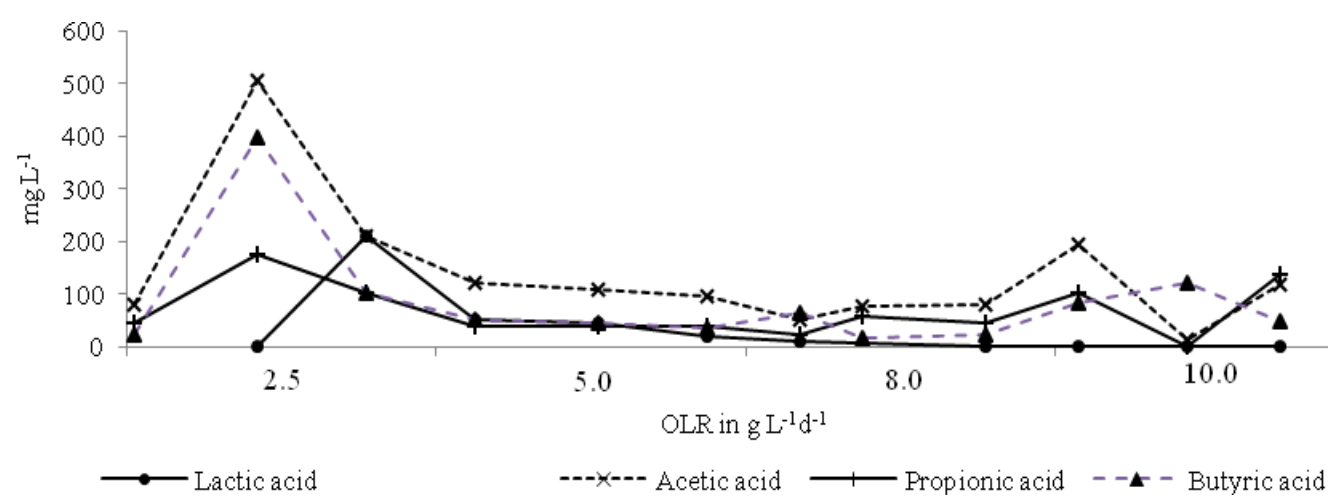

FIGURE 2 .Variation of the concentrations of lactic, acetic, propionic and butyric acids $\left(\mathrm{L}^{-1}\right)$, as a function of the organic loading rate (OLR 2.5, 5.0, 8.0 and $10.0 \mathrm{~g} \mathrm{~L}^{-1} \mathrm{~d}^{-1}$ ).

The accumulation of acids in the reactor indicates the kinetic difference between acidogenic, acetogenic and methanogenic microorganis ms, which results in imbalance between production and consumption of intermediate products, carbon dioxide, hydrogen and acetate (Aquino \& Chernicharo, 2005). In this sense, it is observed that all the acids presented higher concentration in the samples of the load $2.5 \mathrm{~g} \mathrm{~L}^{-1} \mathrm{~d}^{-1}$. This may have occurred because of the recent adaptation of the biomass to the effluent. Over time, there was the microbial community maturation, favoring the consumption of these intermediate acids produced.

The reactions of the production of butyric and propionic acid are the responses of the bacteria to the accumulation of hydrogen in the reactor. These acids are metabolized and converted into acetic acid by acetogenics bacteria, which is used by methanogenic archaeas and converted to methane and carbon dioxide (Shida et al., 2009). This dynamics of production and consumption of volatile organic acids may explain the slight decrease in methane concentration in the biogas produced in the transition from the OLR condition $8.0 \mathrm{~g} \mathrm{~L}^{-1} \mathrm{~d}^{-1}$ to $10.0 \mathrm{~g} \mathrm{~L}^{-}$ ${ }^{1} \mathrm{~d}^{-1}$ (Figure 3), associated to the increase in the concentration of butyric and propionic acids in this phase
(Figure 2), in addition, the increase of the acetic acid concentration in the reactor effluent, can indicate the microfauna inefficiency in the conversion to methane in this condition transition.

The biogas production showed an increasing tendency, in relation to the increase of the organic loading rate, this increase is reflected in the average of biogas production, which varied from $0.81 \mathrm{~L} \mathrm{~d}^{-1}$ (minimum), in the OLR condition $2.5 \mathrm{~g} \mathrm{~L}^{-1} \mathrm{~d}^{-1}$, at $7.56 \mathrm{~L} \mathrm{~d}^{-1}$ (maximum) in the OLR condition $10.0 \mathrm{~g} \mathrm{~L}^{-1} \mathrm{~d}^{-1}$. Comparatively, Torres (2009) obtained good results in relation to the specific biogas production, with averages of 0.527 to $0.985 \mathrm{~L} \mathrm{~g}^{-1}$, higher than the average biogas production obtained in this study, ranging from 0.033 to $0.310 \mathrm{~L} \mathrm{~g}^{-1}$.

On the other hand, the percentage of methane in the biogas decreased with increasing loads, ranging from $76.8 \%$ for the load of $5.0 \mathrm{~g} \mathrm{~L}^{-1} \mathrm{~d}^{-1}$ to $66.1 \%$ in the load of $\left.8.0 \mathrm{~g} \mathrm{~L} \mathrm{~L}^{-1} \mathrm{~d}^{-1}\right)$. Colin et al. (2007) obtained similar percentages of methane, varying from 69 to $81 \%$. Lucas (2015) operating two-phase reactors, fed with starch waste water, obtained $80 \%$ of methane in the biogas volume,

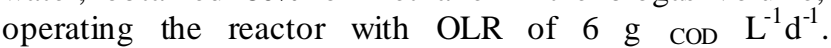

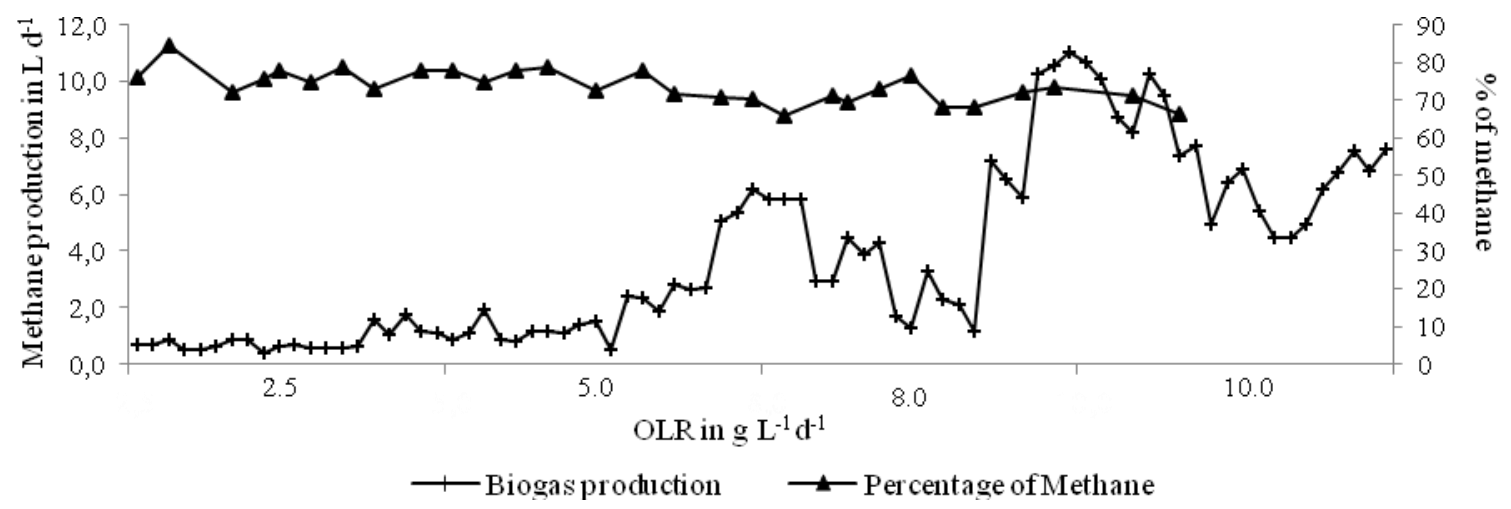

FIGURE 3. Variation of the biogas production and the percentage of methane in the biogas, in function of the organic loading rate (OLR 2.5, 5.0, 8.0 and $10.0 \mathrm{~g} \mathrm{~L}^{-1} \mathrm{~d}^{-1}$ ) 
The specific production of biogas presented an increasing trend in relation to the increase of the organic loading rate, as well as the specific production of methane (Figure 4). The specific biogas production averages ranged from 0.025 to $0.216 \mathrm{~L} g$ $\mathrm{COD}^{-1}$ consumed (OLR of 2.5 and $10.0 \mathrm{~g} \mathrm{~L}^{-1} \mathrm{~d}^{-1}$, respectively). The best adjustment of the trend curves was obtained by the exponential model, obtaining a $\mathrm{R}^{2}$ of 0.74 and 0.60 for the specific production of biogas and methane, respectively.

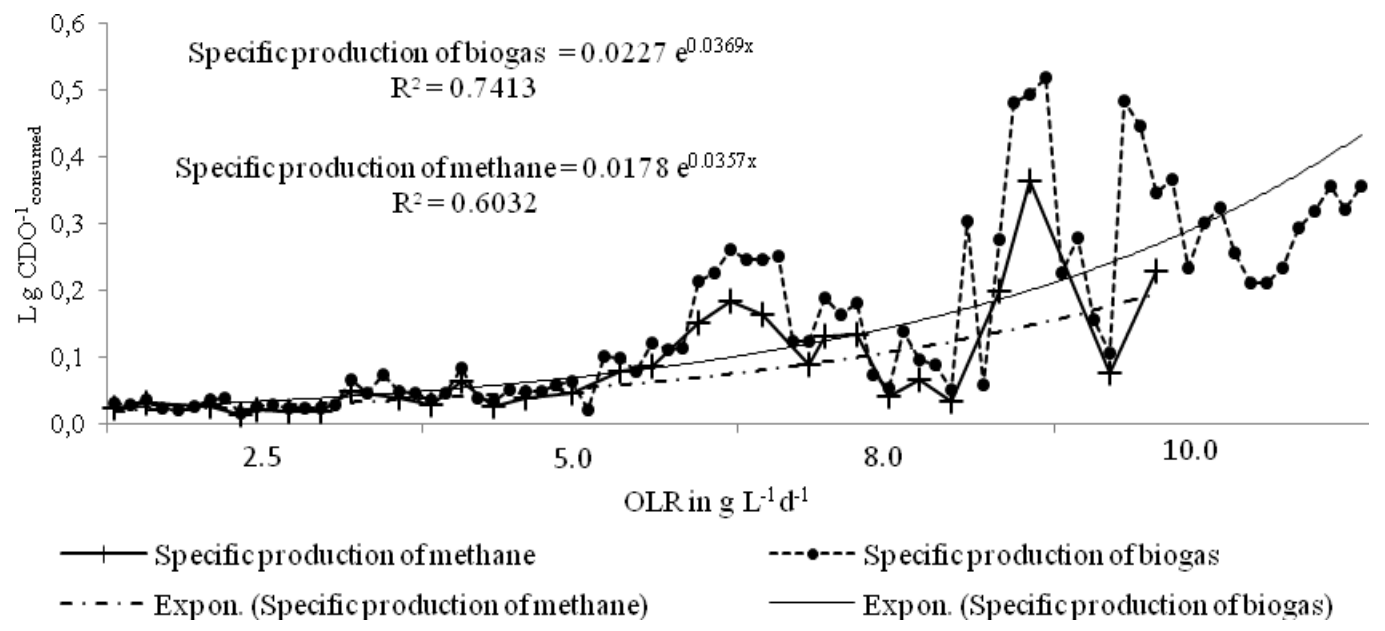

FIGURE 4. Variation of the specific production of biogas and methane in the biogas, in function of the organic loading rate (OLR 2.5, 5.0, 8.0 and $10.0 \mathrm{~g} \mathrm{~L}^{-1} . \mathrm{d}^{-1}$ )

The specific production of methane varied from 0.034 to $0.31 \mathrm{~L} \mathrm{~g}^{-1}$ (OLR of 2.5 and $10.0 \mathrm{~g} \mathrm{~L}^{1} \mathrm{~d}^{1}$ ), with production increasing as the organic loading rate increased. Kuczman et al., $(2014,2016)$ obtained average results of specific biogas production ranging from 0.13 to 0.43 at times of hydraulic detention ranging from 7 to 13 days. The highest specific biogas production was observed with the 10-day holding time and the methane content of $54 \%$ of the total biogas volume. The authors observed a tendency to increase biogas production due to the reduction of hydraulic holding time, although with a 7-day hydraulic detention there was a decrease in production. Even though the authors had less variation in the organic loading rate in relation to this study ( 0.56 to $\left.77 \mathrm{~g} \mathrm{~L}^{1} \mathrm{~d}^{1}\right)$, the results of specific biogas production varied more, probably because it was a reactor in pilot scale, without control of environmental variables. On this aspect, it may have interference in the specific production of biogas in function of temperature control and fluctuations in the quality of the affluent.

Another aspect analyzed in this study concerns the removal of the organic load from the starch effluent, in the proposed reactor configuration. Regarding the COD, it can be observed in Figure 5 that, despite the absolute values of total COD showed large variations, total COD removal (\%) was high, varying from 98.42 to $99.6 \%$ and stable between the evaluated loads. Removal of soluble COD followed standards similar to that of total COD re moval.

The soluble COD, although showing an unstable behavior in OLR $1\left(2.5 \mathrm{~g} \mathrm{~L}^{-1} \mathrm{~d}^{-1}\right)$, stabilized throughout the experiment, ranging from 98.77 to $203.54 \mathrm{mg} \mathrm{L}^{-1}$.

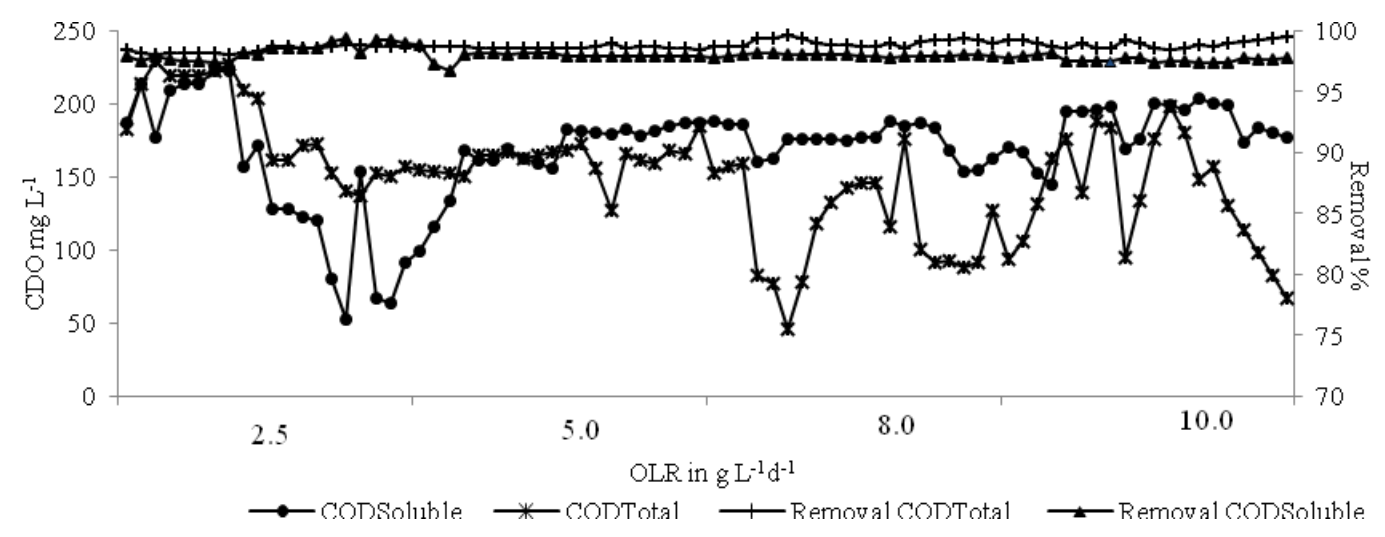

FIGURE 5. Variation of $\mathrm{COD}_{\text {Total }}$ and $\mathrm{COD}_{\text {Soluble }}$ concentrations $\left(\mathrm{mg} \mathrm{L}^{-1}\right)$, as a function of the organic loading rate $(\mathrm{OLR} 2.5$, 5.0, 8.0 and $\left.10.0 \mathrm{~g} \mathrm{~L}^{-1} \cdot \mathrm{d}^{-1}\right)$. 
Comparatively, the reactor obtained removal rates compatible with similar systems tested by Torres (2009), which observed average values of organic matter removal of $98.32 \%$ for the reactor containing bamboo and $98.20 \%$ for the reactor using PVC as support mean, and Colin et al. (2007), applying the load of $11.8 \mathrm{~g} \mathrm{~L}^{-1} \mathrm{~d}^{-1}$ to a fixed-bed reactor and using as substrate the effluent from a cassava starch industry, obtained total COD removal of $87 \%$. Larsen et al. (2013) obtained the best removal of $81.19 \%$ for the organic loading rate of $3.05 \mathrm{~g} \mathrm{~L}^{-1} \mathrm{~d}^{-1}$, without the addition of glycerin. Kunzler et al., (2013) observed removal greater than $98 \%$ at the highest applied load $(5.6 \mathrm{~g}$ $\mathrm{L}^{-1} \mathrm{~d}^{-1}$ ) and average removal efficiency of approximately 93\% for reactors of different lengths, and Kuczman et al. (2016) verified the maximum removal efficiency of approximately $88 \%$ in the organic loading rate of $0.68 \mathrm{~g} \mathrm{~L}^{-}$ ${ }^{1} \mathrm{~d}^{-1}$. In general, methane-fueled reactors with continuous flow and packed bed have good removal rates, higher than $90 \%$. The advantage of the evaluated configuration under the conditions tested was that there was no disturbance regarding COD removal, even with the load changes imposed on the system.

\section{CONCLUSIONS}

1. It is possible to produce biogas with methane percentages above $80 \%$ and remove the organic load by more than $90 \%$ with the reactor configuration tested using wastewater from the cassava starch industry. In relation to stability, the reactor can be considered stable for the parameters, $\mathrm{pH}$, the relationship between volatile acidity and total alkalinity and organic load removal.

2. The best results in relation to the biogas production were obtained for the higher organic loading rate and the observed tendency is that with the increase of the organic loading rate, the specific production of biogas also increases, as well as the specific production of methane.

\section{REFERENCES}

Andreani CL, Torres DGB, Schultz L, Carvalho KQDE, Gomes SD (2015) Hydrogen production from cassava processing wastewater in an anaerobic fixed bed reactor with bamboo as a support material. Engenharia Agrícola 30(45):578-587.

Aquino SF, Chernicharo CA (2005) Acúmu lo de ácidos graxos voláteis (AGV) em reatores anaeróbios sob estresse: causas e estratégias de controle. Engenharia Sanitária e A mbiental 10:152-161.

APHA, AWWA, WEF - A merican Public Health Association, American Water Works Association, Water Environment Federation (2017) Standard methods for the examination of water and wastewater. Washington, Association, American Public Health, 23 rd.

Boonapatcharoen N, Meepian K, Chaip rasert P, Techkarnjanaruk S (2007) Molecular monitoring of microbial population dynamics during operational periods of anaerobic hybrid reactor treating cassava starch wastewater. Microbial Ecology 54(1):21-30.
Campos AT, Daga J, Rodrigues EE, Franzener G, Suguiy MMT, Syperreck VLG (2006) Tratamento de águas residuárias de fecularia por meio de lagoas de estabilização. Engenharia Agrícola 26(1):235-242.

Colin X, Farinet JL, Rojas O, A lazard D (2007) Anaerobic treatment of cassava starch extraction wastewater using a horizontal flow filter with bamboo as support. Bioresource Technology 98(8):1602-1607.

Khongkliang P, Kongjan P, O-Thong S (2015) Hydrogen and methane production from starch processing wastewater by thermophilic two-stage anaerobic digestion. Energy Procedia 79:827-832.

Kuczman O (2012) Tratamento de efluente de fecularia em reator anaeróbio tubular horizontal piloto com meio suporte e agitação. Tese Doutorado, Universidade Estadual do Oeste do Paraná.

Kuczman O, Tavares MHF, Gomes SD, Guedes LPC, Grisotti G (2014) Cas sava starch extraction effluent treatment in a one phase tubular horizontal pilot reactor with support medium. Engenharia Agrícola (45):12701282.

Kuczman O, Tavares MHF, Go mes SD, Guedes LPC, Grisotti G (2016) Effects of stirring on cassava effluent treatment in an anaerobic horizontal tubular pilot reactor with support medium - A Review. Renewable and Sustainable Energy Reviews 77:984-989.

Kunzler KR, Go mes SD, Piana PA, Torres DGB, Vilas Boas MA, Tavares MHF (2013) Anaerobic reactors with biofilter and different diameter-length ratios in cassava starch industry wastewater treatment. Engenharia Agrícola 33(4):612-624.

Larsen AC, Larsen AC, Gomes BM, Gomes SD, Zenatti DC, Torres DGB (2013) Anaerobic co-digestion of crude glycerin and starch industry effluent. Engenharia Agrícola 33(2).

Lucas SD, Torres DGB, Andreani CL, Araujo IRC, Gomes SD (2014) Efeito de diferentes inóculos na produção de biohidrogênio a partir de efluente de fecularia. In: Lat in American Sy mposium of Anaerobic Digestion. Havana, International Water Association, Proceedings...

Lucas SDM (2015) Produção de hidrogênio e metano em reatores anaeróbios de leito fixo em série a partir de efluente de fecularia de mandioca. Tese Doutorado, Universidade Estadual do Oeste do Paraná.

Palma D (2012) Tratamento de água residuária de fecularia em reator anaeróbio com leito fixo de pedras de calcário dolomítico. Tese Mestrado, Universidade Estadual do Oeste do Paraná.

Peixoto G, Saavedra NK, Varesche MBA, Zaiat M (2011) Hydrogen production from soft-drin $\mathrm{k}$ wastewater in an upflow anaerobic packed -bed reactor. International Journal of Hydrogen Energy 36(15):8953-8966. 
Pereira JM, Aquino ACM de S, Oliveira DC de, Rocha G, Francisco A de, Barreto PLM, A mante ER (2016)

Characteristics of cassava starch fermentation wastewater based on structural degradation of starch granules. Ciência Rural 46(4):732-738.

Shida GM, Barros AR, Re is CM dos, Amorim ELC de, Riss ato Zamario lli MHD, Silva EL (2009) Long-term stability of hydrogen and organic acids production in an anaerobic flu idized-bed reactor using heat treated anaerobic sludge inoculum. International Journal of Hydrogen Energy 34(9):3679-3688.

Silva MOS (1977) Análises fisico-químicas para o controle das estações de tratamento de es goto. São Paulo, Cetesb.

Torres DGB (2009) Meios suporte no tratamento anaeróbio da manipueira. Dis sertação Mestrado, Universidade Estadual do Oeste do Paraná.
Torres DGB, Dal' Maso Lucas S, Andreani CL, Carvalho KQ de, Coelho SRM, Go mes SD (2017) Hydrogen production and performance of anaerobic fixed-bed reactors using three support arrangements from cassava starch wastewater. Engenharia Agrícola 37(1):160-172.

Sun L, Wan S, Yu Z, Wang Y, Wang S (2012) Anaerobic biological treat ment of high strength cassava starch wastewater in a new type up-flow mult istage anaerobic reactor. Bioresource Technology 104(3):280-288.

Ward AJ, Hobbs PJ, Holliman PJ, Jones DL (2008) Optimisation of the anaerobic digestion of agricultural resources. Bioresourse Technology 99(17):7928-7940.

Zinatizadeh AAL, Pirsaheb M, Bonakdari H, Younesi H (2010) Response surface analysis of effects of hydraulic retention time and influent feed concentration on performance of an UASFF bioreactor. Waste Management 30:1798-1807. 